\title{
Arsenic contamination in groundwater and its proposed remedial measures
}

\author{
${ }^{1}$ A. Akter; ${ }^{2 *}$ M. H. Ali \\ ${ }^{1}$ Department of Civil and Offshore Engineering, School of Built Environment, Heriot-Watt University, Edinburgh, \\ Scotland, EH144 AS, UK and Department of Civil Engineering, Chittagong University of Engineering and \\ Technology, Chittagong-4349, Bangladesh \\ ${ }^{2}$ Department of Civil Engineering, Chittagong University of Engineering and Technology, Chittagong-4349, \\ Bangladesh and Faculty of Civil Engineering, Universiti Teknologi Malaysia, 81310 UTM Skudai, Johor Darul \\ Ta'zim, Malaysia
}

Received 19 March 2010; $\quad$ revised 29 December 2010; $\quad$ accepted 15 February 2011; $\quad$ available online 1 March 2011

\begin{abstract}
Arsenic contamination occurs in groundwater of Bangladesh mainly from the alluvial and deltaic sediments. Arsenic contamination of groundwater in Bangladesh was first detected more than a decade ago and the 'shallow tubewells' were reported as the main source of arsenic contaminated water. From the nutritional and metabolic points of view, arsenic is likely to adversely affect human health and nutrition. Up to now, several studies have been carried out on this context; however, inadequate knowledge on arsenic sources, mobilization and transport still remains as a constraint due to lack of data, information and technological advances. Thus, a review study has been undertaken on the sources of arsenic, its causes, mobilization, transport, effects on human health, arsenic test procedures and removal methods, in the context of groundwater contamination in Bangladesh, and finally sustainable remedial measures of arsenic have been proposed. This study suggests that laboratory facilities for testing of arsenic and effects of enhanced groundwater pumping, phosphate fertilizer etc., need to be updated, expanded and studied. This review work is significant to further knowledge improvement, as the topic is general and worldwide. It can be concluded that the integration of the proposed remedial measures with the national geographic information system interface database relating to arsenic for analysis, production of hazard maps, and dissemination on television show for the planners, engineers, managers, field supervisors and affected people, can reach at the sustainable solution for mitigating arsenic and associated problems successfully in Bangladesh.
\end{abstract}

Keywords: Arsenic removal methods; Mobilization; Source; Transport

\section{INTRODUCTION}

Arsenic appears in the earth's crust at an average concentration of 2 to $5 \mathrm{mg} / \mathrm{kg}$, with low levels commonly found in the air, water, and soil (Feng et al., 2009). The most common form of As is arsenite and arsenate compounds (Stollenwerk et al., 2007). The toxicity of arsenic follows the order: Inorganic As (III) species $>$ Organic As (III) species > Inorganic As (V) species $>$ Organic As (V) species $>$ Elemental Arsenic. Arsenite is 60 times more toxic than arsenate (Fazal et al., 2001a), and arsenopyrite has been identified as the prime source of As pollution in Bangladesh (Fazal et al., 2001b). Arsenic can be introduced to a groundwater system through various means, including surface water

$\triangle$ *Corresponding Author Email: md_hazrat_ali@cuet.ac.bd Tel./Fax: +60127753 807 and precipitation as well as anthropogenic and naturally occurring sources (Urik et al., 2009; Reza and Singh, 2010). In addition to anthropogenic sources of arsenic contamination, human activity can aggravate and accelerate the release of naturally occurring arsenic (BGS and MacDonald, 2000; Klump et al., 2006). Organic arsenic compounds usually containing carbon, are mainly found in sea-living organisms. Industrial process, such as mining, smelting and coal-fired power plants, found as another source of environmental arsenic (Safiuddin and Karim, 2001; Samarghandi et al., 2007; Mahzuz et al., 2009). Agricultural pesticides and chemicals for timber preservation also play important roles in the presence of arsenic (GomezCaminero et al., 2001; Jha et al., 2010). There are no 
long-term water quality monitoring data to definitively establish how arsenic concentrations change over time (Hossain, 2006). The few data that exist, extending over no more than two years, show that some wells have increased in concentration, but cannot yet be taken as proof of general or systematic changes. On an average, older wells are more likely to be contaminated than recently constructed ones. Only long-term monitoring will determine whether this actually corresponds to increasing concentrations at individual wells (BGS and MacDonald, 2000).

The possible influence of pumping is a key policy issue for the water sector (McArthur et al., 2004). Klump et al. (2006) critically analyzed the negative impact on flow system in the upper $30 \mathrm{~m}$ due to irrigation pumping. Stute et al. (2007) reported that the concentration of arsenic increased proportionally to the increasing groundwater age for the upper $20 \mathrm{~m}$ of the aquifer in Bangladesh. There is extensive withdrawal of groundwater for domestic use and irrigation (Harvey, 2002; Dikinya and Areola, 2010). Although the number of hand pumps is much greater than the number of irrigation wells, they only account for about $10 \%$ of groundwater abstraction by volume. The critical question is whether or not pumping of groundwater for irrigation is either creating or exacerbating the problem of arsenic in drinking water? Although there is evidence that enhanced fluctuation of the water table is not responsible for mobilizing arsenic, this is not to say that irrigation will have no influence on the arsenic problem. In particular, the widespread cultivation of boro rice provides just the conditions that would minimize air entry to the underlying aquifer and would therefore make any ongoing reduction and arsenic release that much more effective (MoA, 2004; Aryafar and Doulati Ardejani, 2009). This process would probably take a long time to have an effect, and cannot account for the large-scale problem that currently exists. Nevertheless, it needs further investigation (BGS and MacDonald, 2000). The effect of phosphate fertilizers also needs investigating as several scientists noted phosphorus involvement in increased As downward movement through leaching from the topsoil (Peryea and Kammereck, 1997). In this stage, phosphate concentrations are abnormally high, frequently more than $0.5 \mathrm{mg} / \mathrm{L}$ (as phosphate, $\mathrm{P}$ ), and this could make the arsenic more soluble by competing with arsenic for sorption sites on the iron oxides (Creger and Peryea, 1994). However, BGS and MacDonald
(2000) suspect that most of the phosphate is derived from natural geological sources. The groundwater arsenic problem in Bangladesh arises because of an unfortunate combination of three factors, namely, source of arsenic (arsenic is present in the aquifer sediments), mobilization (arsenic is released from the sediments to the groundwater) and transport (arsenic is flushed away in the natural groundwater circulation). This study had been carried out in the Department of Civil Engineering, Chittagong University of Engineering and Technology, Bangladesh, during 2006-2009.

\section{Source of arsenic}

Previously a number of anthropogenic explanations had been for the occurrence of arsenic in groundwater. While it is possible that some may explain isolated cases of arsenic contamination, none of the anthropogenic explanations can account for the regional extent of groundwater contamination in Bangladesh and West Bengal (Mandal et al., 1998). There is no doubt that the source of arsenic is of geological (Safiuddin and Karim, 2001). Regional distribution of the high arsenic contaminated water in West Bengal and Bangladesh influenced by the differences in sediment distribution, diagenesis and variations in abstraction depths (Smedley and Kinniburgh, 2002). There have been insufficient analyses of the alluvial sediments to provide a regional picture but current data suggest that arsenic is usually in the range $2-20 \mathrm{mg} / \mathrm{kg}$; only slightly greater than typical sediments (2-6 mg/kg). However, it appears that an unusually large proportion of the arsenic is present in a potentially soluble form (Parsa and Etemad Shahidi, 2010). The high groundwater arsenic concentrations are associated with the grey sands rather than the brown sands (Geen et al., 2003; McArthur et al., 2004). The contamination occurs in groundwater from the alluvial and deltaic sediments that make up much of the area (Bhattacharya et al., 2002). The arsenic is of geological origin and is probably apparent now, because it is only during last 20-30 years that groundwater has been extensively used for drinking water in the rural areas (Jakariya et al., 2003; Jakariya et al., 2007b). Although the mechanism of arsenic release from the sediments is unknown, Stute et al. (2007) suggested that the kinetics of arsenic release from the sediments and the groundwater residence time was an important factor. However, arsenic has probably been presented in the groundwater for thousands of years. 
Much of Bangladesh aquifer system is characterized by a two-aquifer system. A shallow aquifer typically extending from $10 \mathrm{~m}$ to $70 \mathrm{~m}$ below ground level, and a deeper aquifer below about $200 \mathrm{~m}$. A surface layer of silty clay forms a semi-confining layer and a lower clay layer (as thick as $30 \mathrm{~m}$ ) sometimes separates the shallow and deep aquifers or may not be present at all (BGS and DPHE, 2001). Horneman et al. (2004) studied the interface between reduced and oxidized aquifers drops from a depth of $30 \mathrm{~m}$ to $150 \mathrm{~m}$ within a few kilometers in the east of Dhaka. In most of the southern Bangladesh, the situation is much more complex with a division of the shallow aquifer into two by a low permeability silt-clay layer (Harvey et al., 2006; JICA, 2002).

The shallow (or main) aquifer has been extensively exploited and is the source of arsenic problem (Jakariya and Bhattacharya, 2007). Groundwater from depths of more than 150-200 m appears to be essentially arsenicfree. The top of the shallow aquifer, at depths of less than $10 \mathrm{~m}$, also appears to be less contaminated than deeper down and may account in part for observation that shallow hand-dug wells are usually uncontaminated even in areas of otherwise high arsenic contamination (Geen et al., 2005; Jakariya and Bhattacharya, 2007). These wells, however, face the highest risk of microbiological contamination (Caldwell et al., 2003).

It is likely that the original sources of arsenic existed as both sulphide and oxide minerals. Oxidation of pyrite in the source areas and during sediment transport would have released soluble arsenic and sulphate (Polizzotto et al., 2006). The sulphate would have been lost to the sea but the arsenic, as As (V), would subsequently have been sorbed by the secondary iron oxides formed (Root et al., 2009). The mobilizations of arsenic in groundwater system followed by two processes are either by the oxidation of sulfides or the reduction of iron oxides (USEPA, 2006). The 'pyrite oxidation' hypothesis proposed by scientists from West Bengal is therefore unlikely to be a major process and the 'oxyhydroxide reduction' hypothesis is probably the main cause of arsenic mobilization in groundwater (Chowdhury et al., 1999).

Alam and Sattar (2000) found As concentration up to $57 \mathrm{mg} / \mathrm{kg}$ in Bangladeshi soil samples collected from different locations. This As level would be threat on country's staple food rice and also for rice straw-food for cattle. A detailed As survey in soils of Bangladesh has been done by BGS (1999a and b), but no As in Chittagong was found. Hossain (2006) noted that As concentration in rice grain didn't exceed the maximum permissible limit of $1.0 \mathrm{mg} / \mathrm{kg}$, and mentioned that very high level of As (up to $91.8 \mathrm{mg} / \mathrm{kg}$ ) can contaminate rice straw. Hossain (2006) suggested that detailed soil-water-plant chain study can be undertaken in highly As contaminated areas of Bangladesh.

\section{Mobilization of arsenic}

The mobilization of As into groundwater in Bangladesh has been described by researchers under two hypothesis called 'pyrite oxidation' (Mandal et al., 1998; Hossain, 2006) and 'oxy-hydroxide reduction' (Horneman et al., 2004). Microbiological processes had identified in many geochemical transformations in Bangladeshi soils and groundwater, and the microbial activity happen within short time (4 weeks) rather than the residence times of groundwater (4 decades) (Oremland and Stolz, 2005; Harvey et al., 2006). Metalreducing bacteria play important role in arsenic release from the sediments and iron-reducing bacteria are identified as the key organisms that can attack arsenic once they have exhausted iron as a growth element (Islam et al., 2004).

Burial of the sediments, rich in organic matter, has led to the strongly reducing groundwater conditions observed. The process has been aided by the high water table and fine-grained surface layers which impede entry of air to the aquifer. Microbial oxidation of the organic carbon has depleted the dissolved oxygen in the groundwater. This is reflected by the high bicarbonate concentrations found in groundwater in recent sediments. There is a relationship between the degree of reduction of the groundwater and the arsenic concentration; the more groundwater reduction, the more will be the arsenic concentration (Brömssen et al., 2007).

The highly reducing nature of the groundwater has led to the reduction of some of the arsenic to As(III) and possible desorption of arsenic since As(III) is normally less strongly sorbed by the iron oxides than As(V) under the near neutral $\mathrm{pH}$ groundwater conditions observed (Smedley and Kinniburgh, 2002; Hossain, 2006). Further reduction will lead to the partial dissolution of the poorly crystallized ferric oxide with consequent release of iron and additional arsenic (Bhattacharya et al., 1997). Other strongly sorbed ions, especially phosphate, will also be released by iron oxide dissolution. The relatively high phosphate 
concentrations present in the groundwater will compete with arsenic for sorption sites and is another factor that favors high groundwater arsenic concentrations (Harvey et al., 2002). It may also make arsenic treatment more difficult (Brömssen et al., 2007).

\section{Transport of arsenic}

Present groundwater movement is very slow because of the extremely low hydraulic gradients found in the delta region. Except where modified by pumping, groundwater circulation is largely confined to the shallow layers affected by local topographic features and the presence of rivers. Close to rivers, the enhanced groundwater flow may lead to a greater dispersion of arsenic along the river banks. Annual fluctuations of the water table, typically about $5 \mathrm{~m}$, will affect groundwater and arsenic movement in the shallow layers. There may have been some flushing of arsenic from the shallowest layers (BGS and MacDonald, 2000). At greater depths, groundwater moves slowly in response to the small regional gradients (Chowdhury et al., 1999). The lateral and vertical spread of contaminants is slow even without considering the retardation due to sorption. Modeling suggests that even in the most permeable layers, arsenic movement is likely to be limited to a few meters a year (BGS and MacDonald, 2000).

The permeability of the silty clay layers is low and in the case of a narrow horizon of silty clay, water will preferentially move through the adjacent more permeable sandy layers. This effectively protects the silty clay layers from strong leaching and possibly preserves arsenic-rich zones (Larsen et al., 2008). This relative lack of water and arsenic movement and the strong stratification of the aquifer, preserve the high concentrations of arsenic from leaching and lead to the great spatial variability observed. The conclusion from this is that in the absence of human intervention significant short-term (less than a few decades) variations in arsenic concentrations are unlikely to occur at depth (BGS and MacDonald, 2000).

The arsenic contaminated sediments from Himalayans transported down to the floodplain of Bangladesh (Stanger, 2005). Flood is a normal phenomenon in Bangladesh and although the severe flooding in 1998 and 2003 monsoon were exceptional, there may be some increased flow in the uppermost part of the shallow aquifer but this will, if anything, tend tu flush out the arsenic that is found there (BGS and MacDonald, 2000).
Data and information on arsenic occurrences

The following sections deal with the available data and information relating to the occurrences of arsenic in Bangladesh and the effects of arsenic on public health. Arsenic contamination of groundwater was first detected in Bangladesh in 1993 by the Department of Public Health Engineering (DPHE) in Chapai Nawabganj, adjacent to West Bengal, India which was contaminated extensively in 1988 (Smedley and Kinniburgh, 2002; Ahmed et al., 2004). Extensive contamination in Bangladesh was confirmed in 1995 when additional surveys showed contamination of shallow tubewells across much of southern and central Bangladesh. At the same time, cases of chronic arsenicosis were being recognized by health professionals (Bhattacharya et al., 2002).

The presence of arsenic are found so far in tubewells water samples of 60 districts out of 64 districts of Bangladesh and the arsenic contents are found to exceed the World Health Organization (WHO) recommended maximum permissiblelimit (i.e., $0.01 \mathrm{mg} /$ L) in 41 districts (Fig. 1) (BGS and MacDonald, 2000; Caldwell et al., 2003). According to the study conducted by the Department of Public Health Engineering (DPHE) and British Geological Survey (BGS) (BGS and DPHE, 2001), arsenic contents of $46 \%$ of the shallow tubewells water exceed WHO recommended value of $0.01 \mathrm{mg} / \mathrm{L}$ and $27 \%$ shallow tubewells water exceed Bangladesh recommended value of $0.05 \mathrm{mg} / \mathrm{L}$ (Fig. 2).

In acute arsenic problem areas, more than $90 \%$ of shallow tubewells have been found to produce contaminated water exceeding $0.05 \mathrm{mg} / \mathrm{L}$ of arsenic (Tondel et al., 1999; Erickson, 2003). Ninety one percent of the tubewells in Samta village in Jessore district (Biswas et al., 1998), $29 \%$ of the tubewells in Rajarampur village of Nawabganj district (Ahmad et al., 1997) and $59 \%$ of the groundwater samples contain higher than $0.5 \mathrm{mg} / \mathrm{L}$ of arsenic (Chowdhury et al., 1999). The percentage of tubewells reported to affect by arsenic increased from $22 \%$ to $36 \%$ during 1995 to 2004 and people exposed to drink arsenic contaminated water were reported to increase in similar fashion from $21 \%$ in 1995 to $25 \%$ in 2004 of total population of Bangladesh as shown in Fig. 3 (BGS and DPHE, 2001).

In 2008, a total of 282 water samples from shallow tubewells, having a maximum depth of $45 \mathrm{~m}$, were collected from 39 out of 41 Wards of Chittagong City Corporation Area and tested in the field and laboratories 
of Bangladesh University of Engineering and Technology (BUET) and Chittagong University of Engineering and Technology (CUET), respectively (Ashraf and Palit, 2008). They tested the samples in the BUET and CUET laboratories using Atomic Absorption Spectrophotometer and found arsenic concentration values greater than WHO guidelines $(0.01 \mathrm{mg} / \mathrm{L})$ in 13 Wards, the maximum of which was $0.561 \mathrm{mg} / \mathrm{L}$ (WHO, 1993). But no arsenic contamination was found in deep tubewells (deeper than $45 \mathrm{~m}$ ) water. Before these tests, people thought that Chittagong was arsenic-free area. So, it may be assumed that all areas of Bangladesh are being expected to be affected by arsenic gradually.

\section{Effects of arsenic on public health}

There is clearly a very serious problem of arsenic contamination in groundwater in much of southern and eastern Bangladesh (Harvey et al., 2002). Since hand tubewells and shallow tubewells are the major water sources for safe drinking water in rural areas of Bangladesh, arsenic concentration higher than recommend values in these sources have been becoming serious health threat (Chen and Ahsan, 2004; Rahman et al., 2006). Several studies show that the arsenic affected people in Bangladesh are 30 to 35 million (Jakariya et al., 2007a). Serious health hazards can be occurred due to arsenic contaminated drinking water use after a long period of about 5 to 15 years, but the duration can even be 2.5 years for high exposure of contamination (Harvey et al., 2006). Slow As poisoning observed in scalp hair samples among the As contaminated water consumers (Uddin et al., 2006). These range from skin lesions (hyper-pigmentation, de-pigmentation, melanosis, keratosis, etc.) to cancers of the bladder, kidney, lungs and cardiovascular

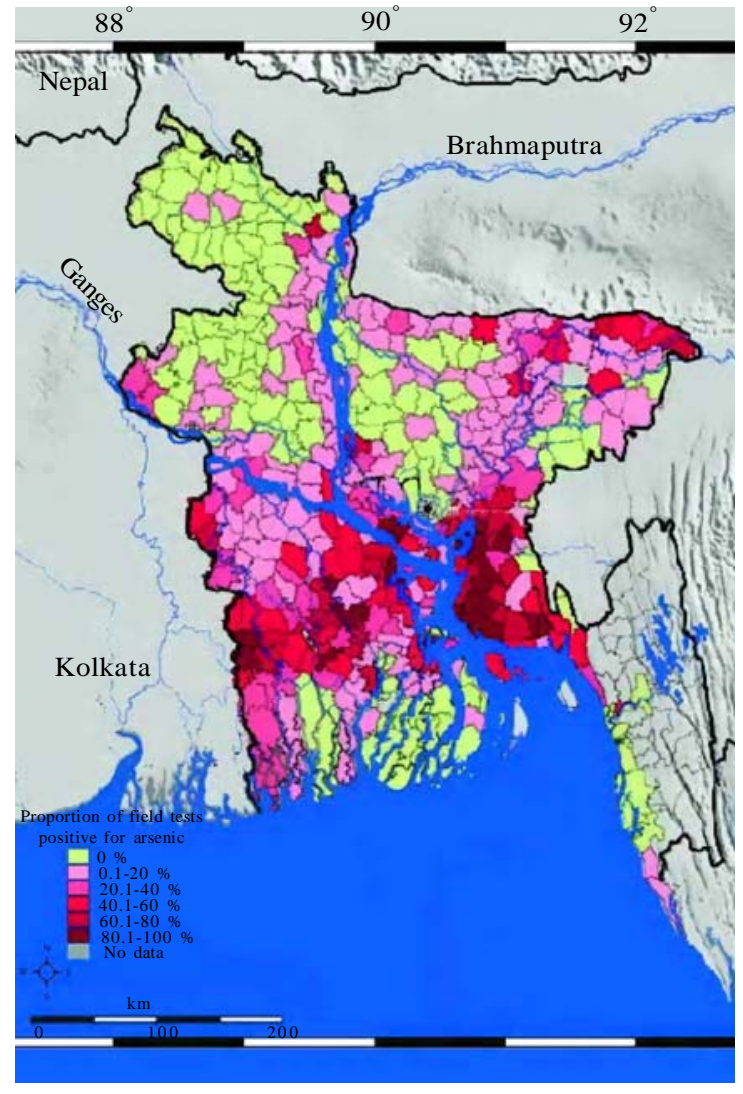

Fig. 1: Distribution of arsenic presence in Bangladesh

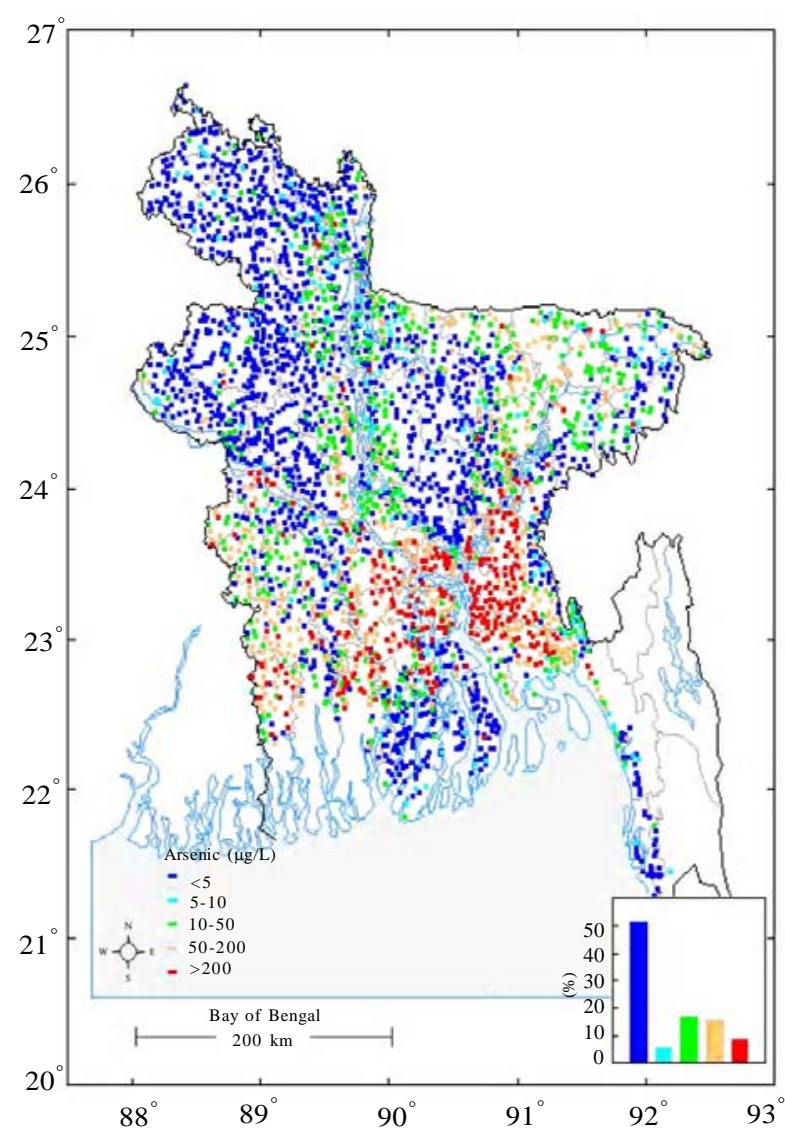

Fig. 2: Arsenic concentration in groundwater of Bangladesh 


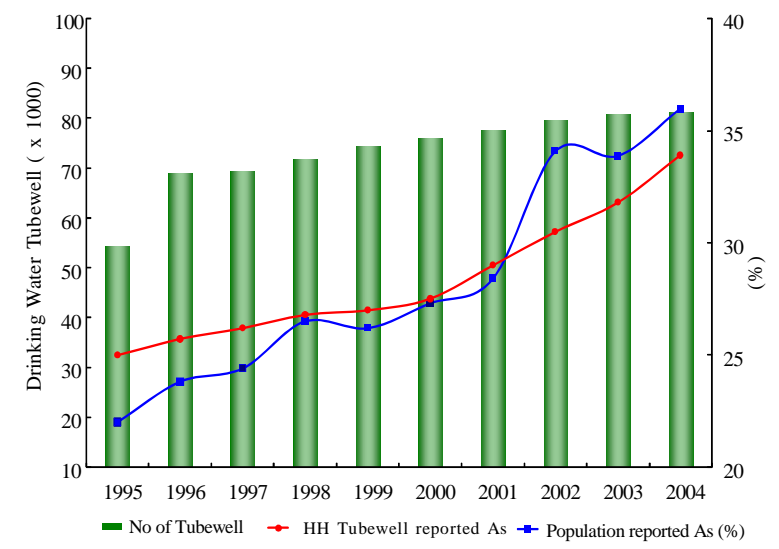

Fig. 3: Percentage of hand tubewells contaminated and population exposed to drink arsenic contaminated water reported having value exceeded by $0.05 \mathrm{mg} / \mathrm{L}$ in Bangladesh

problems (Hossain, 2006). Safiuddin and Karim (2001) reported that the melanosis (93.5\%) and keratosis (68.3\%) are the most common sufferings among the As affected people in Bangladesh. Thereafter, the seriously affected people are by arsenical (arsenite and arsenate), resulting skin cancer of about $0.8 \%$ of the total skin disease patients (Safiuddin and Karim, 2001). The scale of this environmental disaster is greater than any seen before. Chronic arsenicosis plays a crucial role in social and economic consequences as well as through victim's household economy, ultimately decreasing the quality of life (Safiuddin and Karim, 2001).

\section{Testing of arsenic and removal methods and alternatives}

The following sections deal with the arsenic testing methods, and arsenic removal methods and alternatives used in Bangladesh, respectively.

\section{Testing procedures}

During 1997 and 1998, the laboratory facilities for arsenic testing in the DPHE (Dept. of Public Health Engineering) were strengthened with help of WHO, UNICEF (United Nations Children's Fund), DFID (Dept. for International Development) and others. Laboratory facilities for arsenic testing at many public universities in Bangladesh are also available. Nevertheless, the laboratory facilities available within Bangladesh for testing arsenic on a large scale still remain inadequate. Compilation of recent evaluations and other information have produced important information about the practicality of field-kit testing (Geen et al.,
2005; Jakariya et al., 2007a). Several field test kits are employed for short-term screening of As in wells water (Geen et al., 2005; Steinmaus et al., 2006). The general geographical distributions of arsenic contamination indicated by field tests and laboratory tests are essentially the same (BGS and MacDonald, 2000). However, there are problems in testing natural groundwater with low levels of arsenic contamination. Controlled field and laboratory testing in India and Bangladesh showed that:

- Field kits reliably identify highly contaminated water containing above about $0.20 \mathrm{mg} / \mathrm{L}$ of arsenic (Hossain, 2006).

- Field kits do not falsely indicate the presence of arsenic in wells where laboratory tests show the arsenic concentration is below $0.05 \mathrm{mg} / \mathrm{L}$ (Rahman et al., 2002).

- Field kits do not reliably identify the presence of arsenic in groundwater contaminated containing between 0.05 and $0.20 \mathrm{mg} / \mathrm{L}$ of arsenic.

- It should be noted that these tests were performed either by or under the supervision of chemists. Therefore, actual results performed without supervision may add additional uncertainty to the results.

There is a substantial ongoing effort to improve these field test kits ready for a country-wide screening process (BGS and MacDonald, 2000). Hossain (2006) reported that the UNICEF is going to use some improved field test kits like Arsenator, kit with photometer (developed by Mahidol University in Thailand), and kit based on the molybdenum blue method which does not produce arsine gas (Hussam et al., 1999; Christen, 2001).

\section{Arsenic removal methods and alternatives}

Sorg and Logsdon (1974) reviewed arsenic removal technologies intensively. The most commonly used As removal methods are oxidation, co-precipitation and adsorption onto coagulated flocs, lime treatment, adsorption onto sorptive media, ion exchange resin and membrane techniques (Hering et al., 1996, 1997; Joshi and Chaudhuri, 1996). Jekel (1994) and Ahmed (2001) documented several advantages and disadvantages in arsenic removal technologies.

Geochemical studies in water supply system could provide insight into the biogeochemical controls on arsenic mobility by well-defined arsenic and iron inputs. For water treatment by coagulation with hydrolyzing Fe (III) shows higher efficiencies for As (V) over oxidation method (Gomez-Caminero et al., 2001). 
Passive sedimentation, i.e., combination of oxidation and subsequent storing of As contaminated water for long duration, could be a useful method among rural people of Bangladesh (Ahmed, 2001). The basic concept of ultraviolet radiation to catalyze the oxidation process of arsenite in presence of oxygen was experimented as a method of As removal (Wegelin et al., 2000). Ahmed (2001) argued that solar oxidation of arsenic in transparent bottle can reduce about one third of As from contaminated water sample of Bangladesh.

The Bucket Treatment Unit (BTU), developed by DPHE-DANIDA project in Bangladesh, is based on the principles of coagulation (using different coagulants like aluminium alum, ferric salts, etc.), co-precipitation (using aluminium hydroxide) and adsorption processes (Ahmed, 2001). In this method two buckets, each of 20litre capacity, can remove As by about 2-3 hrs. Another two buckets technology is the Stevens Institute Technology, chemicals mixing bucket (reported to be iron sulphate and calcium hypochloride) supplied in packets and the flocs separation bucket using the processes of sedimentation and filtration. This technology can reduce As level to less than $0.05 \mathrm{mg} / \mathrm{L}$ in 80 to $95 \%$ cases (BAMWSP et al., 2001). Based on the coagulation process followed by sand filtration, Bangladesh Council of Scientific and Industrial Research (BCSIR) developed an arsenic removal system. A combination of oxidation, coagulation and sedimentation process is involved in Fill and Draw Units by DPHEDANIDAArsenic Mitigation Pilot Project (Sarkar and Rahman, 2001).

In 2004, the BCSIR certified three households a chemical and a non-chemical arsenic removal plant that could filter arsenic. The BCSIR with the technical assistance of a Canadian NGO (non-government organization), the Ontario Centre for Environmental Technology Advancement, has been evaluating five technologies for the last two years. Of those, Alcan, Sidko, READ-F and Sono (Table 1) are validated in the field tests and achieved the BCSIR authorization (The Daily Star, 2004a). A handy, simple and cheap 'Sono' filter made of easily available materials has worked wonders in supplying arsenic-free water to rural people. Its use has stopped spread of arsenicosis in about 100 villages in Kushtia Sadar, Khoksa, Daulatpur and Bheramara upazilas. No arsenicosis patient was detected in these villages in the last two years after people started using it, reported by the innovators who are producing and marketing this filter (The Daily Star, 2006). Sono Filter is perhaps the first recognized successful indigenous technology to remove arsenic from water. It costs between \$25 and \$35 (BDT 1600 and BDT 2100) and a buyer does not have to use any ingredient or chemical to purify water. These filters can produce $120 \mathrm{~L}$ (at $30 \mathrm{~L} / \mathrm{h}$ ) of clean water for drinking and cooking. It can last at least 5 years without a toxic waste disposal hazard. Three scientists of Bangladesh, namely, Dr. Munir, a physician in Kushtia, Bangladesh; Prof. Abul Hussam, Department of Chemistry and BioChemistry, George Mason University, USA(Bangladesh born US citizen); and Prof. Abul Barkat, Economics Department, Dhaka University, Bangladesh, have invented the system after seven years of experiments. It is now made of two buckets using iron dust, saw dust, coal and some other components, which the innovators are not willing to elaborate. It has been approved by the World Health Organization (WHO), the Bangladesh government and the local bureau of Isotope Hydrology Section of the Inter-national Atomic Energy Agency (IAEA). Manab Sakti Unnayan Kendro (MSUK), a sister organization of Sono Diagnostic Center (CDC), has been supervising its production. They said about 27000 Sono filters have been sold so far to the people across the country. Different NGO's across the country are also marketing it. People in Chapi Nawabganj municipality area are one of the worst arsenic-affected people in the country. At present, most of the deep tubewells supplying water through

Table 1: Arsenic removal process and their costs for the BCSIR authorized technology

\begin{tabular}{|c|c|c|c|}
\hline Technology & As removal process & $\begin{array}{l}\text { Capital, } \mathrm{O} \text { and } \\
\text { M cost (Tk.) }\end{array}$ & $\begin{array}{l}\text { Cost (Tk/L } \\
\text { of water) }\end{array}$ \\
\hline Alcan & Using activated alumia as Sorptive filtration media. & 3500 & 0.18 \\
\hline Sidko & Usage of the granular Ferric Hydroxide (AdsorpAs®) as adsorbent. & 350,000 & 0.18 \\
\hline READ-F & $\begin{array}{l}\text { Ethylenevinyl alcohol copolymer (EVOH)-borne hydrous cerium oxide } \\
\text { whereas the hydrous cerium oxide is the adsorbent. }\end{array}$ & 5500 & 0.19 \\
\hline Sono & $\begin{array}{l}\text { Zero valent iron fillings and coarse sand used in the } \\
\text { top bucket made by indigenous iron rich clay. }\end{array}$ & 2700 & 0.12 \\
\hline
\end{tabular}


pipelines to about 240,000 people are contaminated by the groundwater arsenic. A deep tubewell is installed on the bank of the River Mahananda to pump out 30,000 gallons of water an hour and to supply arsenic free water to around 30 villages severely affected by groundwater arsenic contamination (The Daily Star, 2004b). According to the DPHE survey report for Brahmanbaria, about 488,650 people suffered from highly arsenic contaminated water of about $84 \%$ of the total 28,068 numbers of tube-wells, while the rest tube-wells were completely out of order because of the layer of arsenic contaminated water at $30 \mathrm{~m}$ depth. This problem was overcome by DPHE by installing deep tube-wells at about $210 \mathrm{~m}$ depth in different parts of the affected areas (Islam et al., 2004).

\section{RESULTS AND DISCUSSION}

The laboratory facilities available for testing arsenic on a large scale have still been remained inadequate in Bangladesh, although an increasing number of private laboratories have been offering sophisticated arsenic testing facilities. Thus, further improvement and expansion of the laboratories at government level might help arsenic test on a large scale. Both field and laboratory testing are required on a massive scale, or perhaps a combination of the two, or perhaps mobile arsenic-testing laboratories. Many tubewells were reported safe a long time ago by individual initiation, but unfortunately many of these wells had been contaminated with high level of As, indicating spreading of As contamination (Christen, 2001; Erickson, 2003). Erickson (2003) proposed that the wells should be tested more than once and Hossain (2006) supported this proposal for the repeated testing by the government or donor agencies. Cheng et al. (2004) emphasized on the monitoring of the seasonal and temporal variations of As in the groundwater of Bangladesh. So, the initial step would be to test all shallow tubewells water across the country and declared safe or unsafe for drinking. Thereafter, routine maintenance/testing step should follow properly.

\section{Implementation of alternative sources}

The potential alternative sources could be the treated surface, dug wells, pond-sand-filters (PSF), rainwater-harvested (RWH) and deep tubewells water. Jakariya et al. (2007b) also noted three potential sources, namely, treated surface water, rain water and alternative ground water (Safiuddin and Karim, 2001; Geen et al., 2003). The approach can be started by continuing the existing color distinction between acceptable/non-acceptable hand tubewells for drinking purpose. This can be followed by installing deep tubewells in stratified aquifer in Bangladesh (Stollenwerk, 2007), or community based surface water treatment plant. Individual initiative can go for household rainwater harvesting, or use of dug-well water. National initiative can be taken to supply treated surface water or arsenic free deep-tubewell water to the arsenic affected areas. Iron-cum-arsenic removal plant or salinity-cum-arsenic removal plant can also be set up at a specific location of concern at government and non-government levels. Few of these alternatives are available in Bangladesh, but are not applied effectively due to lack of funds, lack of sound knowledge in groundwater hydrology, proper planning and management. However, these approaches can be integrated to reach at the sustainable solution for mitigating arsenic and associated problems in Bangladesh.

\section{CONCLUSION}

Although relevant data and information are available in the literature on arsenic, this review study has been completed in concise form to compile important information in order to propose remedial measures of arsenic in the context of Bangladesh. This review work suggests that the effect of phosphate fertilizer on solubility of arsenic in groundwater; the impacts of using arsenic contaminated irrigation water from shallow tube-wells on human food chain, animal food chain and soil quality; the effect of enhanced fluctuation of groundwater table; the effect of enhanced pumping; the possible increment of arsenic concentration over time, the effect of long-term flooding in arsenic affected areas, etc., need to be investigated thoroughly to handle arsenic problems successfully in Bangladesh. The proposed remedial measures would be much more successful if sound planning and management programs are undertaken jointly by the government, non-governmental organizations, local authorities and individual households, to integrate these remedial measures in order to reach at the sustainable solution for mitigating arsenic and associated problems successfully in Bangladesh. The proposed remedial measures would be much more successful if sound planning and management programs are undertaken jointly by the government, non-governmental organizations, local authorities and 
individual households to integrate these remedial measures in order to reach at the sustainable solution for mitigating arsenic and associated problems in Bangladesh. Moreover, the integration of these suggested measures with the national GIS interface database relating to arsenic for analysis, production of hazard maps, dissemination of related results on television show, etc., might play crucial roles for the planners, designers, managers, field supervisors and affected people.

\section{ACKNOWLEDGEMENTS}

This study was supported by funds provided by the Department of Civil Engineering, Chittagong University of Engineering and Technology, Bangladesh. Sincere thanks are due to the staff of Chittagong University of Engineering and Technology and Universiti Teknologi Malaysia, for providing necessary supports to carry out this study.

\section{REFERENCES}

Ahmad, S. A.; Bandaranayake, D.; Khan, A. W.; Hadi, S. A.; Uddin, G.; Halim, M. A., (1997). Arsenic contamination in groundwater and arsenicosis in Bangladesh. Int. J. Environ. Health Res., 7 (4), 271-276 (6 pages).

Ahmed, K. M.; Bhattacharya, P.; Hasan, M. A.; Akhter, S. H.; Alam, S. M. M.; Bhuyian, M. A. H., (2004). Arsenic enrichment in groundwater of the alluvial aquifers in Bangladesh: An Overview. Appl. Geochem., 19 (2), 181200 (20 pages).

Ahmed, M. F., (2001). An overview of arsenic removal technologies in Bangladesh and India. Technologies for arsenic removal from drinking water, a compilation of papers presented at the International workshop on technologies for arsenic removal from drinking water organized by Bangladesh University of Engineering and Technology (BUET), Dhaka, Bangladesh and The United Nations University (UNU), Tokyo, Japan, 251-269 (19 pages).

Alam, M. B.; Sattar, M. A., (2000). Assessment of As contamination in soils and waters in some areas of Bangladesh. Water Sci. Tech., 42 (7-8), 185-193 (9 pages).

Aryafar, A.; Doulati Ardejani, F., (2009). Anisotropy and bedding effects on the hydro geological regime in a confined aquifer to design an appropriate dewatering system. Int. J. Environ. Sci. Tech., 6 (4), 563-570 (8 pages).

Ashraf, M. A.; Palit, S. K., (2008). Arsenic screening of groundwater from tubewells located within Chittagong City. Research Report, CUET and IEB Chittagong Centre.

BAMWSP; DFID; WaterAid Bangladesh, (2001). Rapid assessment of household level arsenic removal technologies. Phase-I and Phase-II, Final Report WS Atkins International Limited.

BGS, (1999a). Groundwater studies for arsenic contamination in Bangladesh. Main Report and Supplemental volumes 1-3, Government of the Peoples Republic of Bangladesh, Ministry of Local Government, Rural Development and Cooperatives,
Department of Public Health Engineering, Dhaka, Bangladesh and Mott MacDonald Int. Ltd. UK

BGS, (1999b). Arsenic contamination of ground water in Bangladesh. Technical Report, WC/00/19, 1.

BGS; DPHE, (2001). Arsenic contamination of groundwater in Bangladesh. In: Kinniburgh DG, Smedley PL, (Ed). BGS Technical Report. WC/00/19, Keyworth: BGS.

BGS; MacDonald, M., (2000). Phase I: Groundwater Studies of Arsenic Contamination in Bangladesh. Executive Summary, Main Report, WC/00/19.

Bhattacharya, P.; Chatterjee, D.; Jacks G., (1997). Occurrence of arsenic contaminated groundwater in alluvial aquifers from Delta Plains, Eastern India: Options for safe drinking water supply. Int. J. Water Resour. Dev., 13 (1), 79-92 (14 pages).

Bhattacharya, P.; Jacks, G.; Ahmed, K. M.; Routh, J.; Khan, A. A., (2002). Arsenic in groundwater of the Bengal delta plain aquifers in Bangladesh. Bull. Environ. Contam. Tech., 69 (4), 538-545 (8 pages).

Biswas, B. K.; Dhar, R. K.; Samanta, G.; Mandal, B. K.; Chakraborti, D.; Faruk, I., (1998). Detailed study report of Samta, one of the arsenic-affected villages of Jessore district, Bangladesh. Curr. Sci., 74 (2), 134-145 (12 pages).

Brömssen, M. V.; Jakariya, M.; Bhattacharya, P.; Ahmed, K. M.; Hasan, M. A.; Sracek, O., (2007). Targeting low-arsenic aquifers in Matlab upazila, Southeastern Bangladesh. Sci. Total Environ., 379 (2-3), 121-132 (12 pages).

Caldwell, B. K.; Caldwell, J. C.; Mitra, S. N.; Smith, W., (2003). Tubewells and arsenic in Bangladesh: Challenging a public health success story. Int. J. Popul. Geogr., 9 (1), 23-38 (16 pages).

Chen, Y.; Ahsan, H., (2004). Cancer burden from arsenic in drinking water in Bangladesh. Am. J. Public Health, 94 (5), 741-744 (4 pages).

Cheng, Z; vanGeen, A.; Jing, C.; Meng, X.; Seddique, A. A.; Ahmed, K. M., (2004). Performance of a household-level arsenic removal system during 4-month deployments in Bangladesh. Environ. Sci. Tech., 38, 3442-3448 (7 pages).

Chowdhury, T. R.; Basu, G. K.; Mandal, B. K.; Biswas, B. K.; Samanta, G.; Chowdhury, U. K., (1999). Arsenic poisoning in the Ganges Delta. Nature, 401, 545-546 (2 pages).

Christen, K., (2001). The arsenic threat worsens. Environ. Sci. Tech., 35 (13), 286A-291A (6 pages).

Creger, T. L.; Peryea, F. J., (1994). Phosphate fertilizer enhances As uptake by apricot liners grown in LeadArsenate-enriched soil. Horticultural Sci., 29 (2), 88-92 (5 pages).

Dikinya, O.; Areola, O., (2010). Comparative analysis of heavy metal concentration in secondary treated wastewater irrigated soils cultivated by different crops. Int. J. Environ. Sci. Tech., 7 (2), 337-346 (10 pages).

Erickson, B. E., (2003). Field kits to provide accurate measure of As in groundwater. Environ. Sci.Tech., 37 (1), 35A-38A (4 pages).

European Union (EU), (1998). Council directive 98/83/EC on the quality of water intended for human consumption. J. Eur. Commun., L 330/32, 32-54 (23 pages).

Fazal, M. A.; Kawachi, T.; Ichion, E., (2001a). Extent and severity of groundwater arsenic contamination in Bangladesh. Water Int., 26 (3), 370-379 (10 pages). 
Fazal, M. A.; Kawachi, T.; Ichion, E., (2001b). Validity of the latest research findings on causes of groundwater arsenic contamination in Bangladesh. Water Int., 26 (2), 380-389 (10 pages).

Feng, X. D.; Huang, W. L.; Yang, C.; Dang, Z., (2009). Chemical speciation of fine particle bound trace metals. Int. J. Environ. Sci. Tech., 6 (3), 337-346 (10 pages).

Geen, A. V.; Cheng, Z.; Seddique, A. A.; Hoque, M. A.; Gelman, A.; Graziano, J. H., (2005). Reliability of a commercial kit to test groundwater for arsenic in Bangladesh. Environ. Sci. Tech., 39 (1), 299-303 (5 pages).

Geen, A. V.; Zheng, Y.; Versteeg, R.; Stute, M.; Horneman, A.; Dhar, R., (2003). Spatial variability of arsenic in 6000 tubewells in a $25 \mathrm{~km}^{2}$ area of Bangladesh. Water Resour. Res., 39 (5), 1140-1155 (16 pages).

Gomez-Caminero, A.; Howe, P.; Hughes, M.; Kenyon, E.; Lewis, D. R.; Moore, M., (2001). Arsenic and arsenic compounds. Environmental Health Criteria 224, United Nations Environment Programme, the International Labour Organization, and the World Health Organization.

Harvey, C. F., (2002). Groundwater flow in the Ganges Delta. Sci., 296, 1563-1563 (1 pages).

Harvey, C. F.; Ashfaque, K. N.; Yu, W.; Badruzzaman, A. B. M.; Ali, M. A.; Oates, P. M., (2006). Groundwater dynamics and arsenic contamination in Bangladesh. Chem. Geology, 228 (1-3), 112-136 (25 pages).

Harvey, C. F.; Swartz, C. H.; Badruzzaman, A. B. M.; KeonBlute, N.; Yu, W.; Ali, M. A., (2002). Arsenic mobility and groundwater extraction in Bangladesh. Sci., 298 (5598), 16021606 (5 pages).

Hering, J. G.; Chen, P.; Wilkie, J. A.; Elimelech, M., (1997). Arsenic removal from drinking water during coagulation. J. Environ. Eng., 123 (8), 800-807 (8 pages).

Hering, J. G.; Chen, P. Y.; Wilkie, J. A.; Elimelech, M.; Liang, S., (1996). Arsenic removal by ferric chloride. J. Am. Water Works Assoc. (AWWA), 88 (4), 155-167 (13 pages).

Horneman, A.; vanGeen, A.; Kent, D. V.; Mathe, P. E.; Zheng, Y.; Dhar, R. K., (2004). Decoupling of As and Fe release to Bangladesh groundwater under reducing conditions, Part I: Evidence from sediment profiles. Geochim Cosmochim Acta, 68 (17), 3459-3473 (15 pages).

Hossain, M. F., (2006). Arsenic contamination in BangladeshAn overview. Agric. Ecosyst. Environ., 113 (1-4), 1-16 (16 pages).

Hussam, A.; Alauddin, M.; Khan, A. H.; Rasul, S. B.; Munir, A. K. M., (1999). Evaluation of arsine generation in arsenic field kit. Environ. Sci. Tech., 33 (20), 3686-3688 (3 pages).

Islam, F. S.; Gault, A. G.; Boothman, C.; Polya, D. A.; Charnock, J. M.; Chatterjee, D., (2004). Role of metal-reducing bacteria in arsenic release from Bengal delta sediments. Nature, 430 (6995), 68-71 (4 pages).

Jha, B. R.; Waidbacher, H.; Sharma, S.; Straif, M., (2010). Study of agricultural impacts through fish base variables in different rivers. Int. J. Environ. Sci. Tech., 7 (3) 609-615 (7 pages).

Jakariya, M.; Bhattacharya, P., (2007). Use of GIS in local level participatory planning for arsenic mitigation: A case study from Matlab Upazila, Bangladesh. J. Environ. Sci. Health, 42 (12), 1933-1944 (12 pages).

Jakariya, M.; Bromssen, M. V.; Jacks, G.; Chowdhury, A. M. R.; Ahmed, K. M.; Bhattacharya, P., (2007b). Searching for a sustainable arsenic mitigation strategy in Bangladesh: Experience from two Upazilas. Int. J. Environ. Pollut., 31 (3-4), 415-430 (16 pages).

Jakariya, M.; Chowdhury, A. M. R.; Hossain, Z.; Rahman, M.; Sarker, Q.; Khan, R. I., (2003). Sustainable community-based safe water options to mitigate the Bangladesh arsenic catastrophe-An experience from two Upazilas. Curr. Sci., 85 (2), 141-146 (6 pages).

Jakariya, M.; Vahter, M.; Rahman, M.; Wahed, M. A.; Hore, S. K.; Bhattacharya, P., (2007a). Screening of arsenic in tubewell water with field test kits: Evaluation of the method from public health perspective. Sci. Total Environ., 379 (2-3), 167-175 (9 pages).

Jekel, M. R., (1994). Removal of arsenic in drinking water treatment. In: J. O. Nriagu (Ed.), Arsenic in the Environment, Part 1: Cycling and Characterization, John Wiley \& Sons, Inc., New York.

JICA (Japanese International Cooperation Agency), (2002). The study on ground water development of deep aquifers for safe drinking water supply to arsenic affected areas in Western Bangladesh. Kokusai Kogyo Co. Ltd., and Mitsui Mineral Development Engineering Co. Ltd.

Joshi, A.; Chaudhury, M., (1996). Removal of arsenic from groundwater by iron-oxide-coated sand. J. Environ. Eng., 122 (8), 769-771 (3 pages).

Klump, S.; Kipfer R.; Cirpka O. A.; Harvey, C. F.; Brennwald, M. S.; Ashfaque, K. N., (2006). Groundwater dynamics and arsenic mobilization in Bangladesh assessed using noble gases and tritium. Environ. Sci. Tech., 40 (1), 243-250 (8 pages).

Larsen, F.; Pham, N. Q.; Dang, N. D.; Postma, D.; Jessen, S.; Pham, V. H., (2008). Controlling geological and hydrogeological processes in an arsenic contaminated aquifer on the red river flood plain, Vietnam. Appl. Geochem., 23 (11), 3099-3115 (17 pages).

Mahzuz, H. M. A.; Alam, R.; Alam, N. M.; Basak, R.; Islam, S. M., (2009). Use of arsenic contaminated sludge in making ornamental bricks. Int. J. Environ. Sci. Tech., 6 (2) 291-298 (8 pages).

Mandal, B. K.; Chowdhury, T. R.; Samanta, G.; Mukherjee, D. P.; Chanda, C. R.; Saha, K. C., (1998). Impact of safe water for drinking and cooking on five arsenic-affected families for 2 years in West Bengal, India. Sci. Total Environ., 218 (2-3), 185-201 (17 pages).

McArthur, J. M.; Banerjee, D. M.; Hudson-Edwards, K. A.; Mishra, R.; Purohitb, R.; Ravenscroft, P., (2004). Natural organic matter in sedimentary basins and its relation to arsenic in anoxic ground water: The example of West Bengal and its worldwide implications. Appl. Geochem., 19 (8), 1255-1293 (39 pages).

MoA, (2004). Handbook of agricultural statistics. Sector Monitoring Unit, Ministry of Agriculture (MoA).

Oremland, R. S.; Stolz, J. F., (2005). Arsenic, microbes and contaminated aquifers. Trend. Microbiol., 13 (2), 45-49 (5 pages).

Parsa, J.; Etemad Shahidi, A., (2010). Prediction of tidal excursion length in estuaries due to the environmental changes. Int. J. Environ. Sci. Tech., 7 (4) 675-686 (12 pages).

Peryea, F. J.; Kammereck, R., (1997). Phosphate-enhanced movement of arsenic out of lead arsenate contaminated topsoil and through uncontaminated subsoil. Water Air Soil Pollut., 93 (1-4), 243-254 (12 pages) 
Polizzotto, M. L.; Harvey, C. F.; Li, G.; Newville, M.; Fendorf, S., (2006). Solid-phases and desorption processes of arsenic within Bangladesh sediments. Chem. Geology, 228 (1-3), 97-111 (15 pages).

Rahman, M.; Vahter, M.; Wahed, M. A.; Sohel, N.; Yunus, M.; Streatfield, P. K., (2006). Prevalence of arsenic exposure and skin lesions. A population based survey in Matlab, Bangladesh. J. Epidemiol. Commun. Health, 60, 242-248 (7 pages).

Rahman, M. M.; Mukherjee, D.; Sengupta, M. K.; Chowdhury, U. K.; Lodh, D.; Chanda, C. R., (2002). Effectiveness and reliability of arsenic field testing kits: Are the million dollar screening projects effective or not? Environ. Sci. Tech., 36 (24), 5385-5394 (10 pages).

Reza, R.; Singh, G., (2010). Heavy metal contamination and its indexing approach for river water. Int. J. Environ. Sci. Tech., 7 (4), 785-792 (8 pages).

Root, R. A.; Vlassopoulos, D.; Rivera, N. A.; Rafferty, M. T.; Andrews, C.; O’Day, P. A., (2009). Speciation and natural attenuation of arsenic and iron in a tidally influenced shallow aquifer. Geochimica et Cosmochimica Acta, 73 (19), 5528-5553 (26 pages).

Safiuddin, M.; Karim, M. M., (2001). Groundwater arsenic contamination in Bangladesh: Causes, effects and remediation. Proceedings of the $1^{\text {st }}$ IEB International Conference and $7^{\text {th }}$ Annual Paper Meet, The Institution of Engineers, Chittagong Center, Bangladesh.

Samarghandi, M. R.; Nouri, J.; Mesdaghinia, A. R.; Mahvi, A. H.; Nasseri, S.; Vaezi, F., (2007). Efficiency removal of phenol, lead and cadmium by means of UV/ TiO2/ H2O2 processes. Int. J. Environ. Sci. Tech., 4 (1), 19-26 (8 pages).

Sarkar, A. R.; Rahman, O. T., (2001). In-situ removal of arsenic-experiences of DPHE-DANIDA pilot project. Technologies for arsenic removal from drinking water, a compilation of papers presented at the International workshop on technologies for arsenic removal from drinking water organized by Bangladesh University of Engineering and Technology (BUET), Dhaka, Bangladesh and The United Nations University (UNU), Tokyo, Japan, 201-206 (6 pages).

Smedley, P. L.; Kinniburgh, D. G., (2002). A review of the source, behavior and distribution of arsenic in natural waters. Appl. Geochem., 17 (5), 517-568 (52 pages).

Sorg, T. J.; Logsdon, G. S., (1974). Treatment technology to meet the interim primary drinking water regulations for inorganics: Part 2. J. Am. Water Works Assoc., 70 (7), 379-393 (15 pages).

Stanger, G., (2005). A Paleo-Hydrogeological model for arsenic contamination in Southern and South-East Asia. Environ. Geochem. Health, 27 (4), 359-368 (10 pages).

Steinmaus, C. M.; George, C. M.; Kalman, D. A.; Smith, A. H., (2006). Evaluation of two new arsenic field test kits capable of detecting arsenic water concentrations close to $10 \mu \mathrm{g} / \mathrm{L}$. Environ. Sci. Tech., 40 (10), 3362-3366 (5 pages).

Stollenwerk, K. G.; Breit, G. N.; Welch, A. H.; Yount, J. C.; Whitney, J. W.; Foster, A. L., (2007). Arsenic attenuation by oxidized aquifer sediments in Bangladesh. Sci. Total Environ., 379 (2-3), 133-150 (18 pages).

Stute, M.; Zheng, Y.; Schlosser, P.; Horneman, A.; Dhar, R. K.; Datta, S., (2007). Hydrogeological control of As concentrations in Bangladesh groundwater. Water Resour. Res., 43, W09417.

The Daily Star, (2004a). Arsenic-free water from next month. 4 (292).

The Daily Star, (2004b). Govt. okays marketing of antiarsenic technologies. 4 (266).

The Daily Star, (2006). A wonder filter that gives arsenicfree water. 5 (689).

Tondel, M.; Rahman, M.; Magnuson, A.; Chowdhury, I. A.; Faruquee, M. H.; Samad, S. A., (1999). The relationship of arsenic levels in drinking water and the prevalence rate of skin lesions in Bangladesh. Environ. Health Perspect., 107, 727-729 (3 pages).

Uddin, M. M.; Harun-Ar-Rashid, A. K. M.; Hossain,S. M.; Hafiz, M. A.; Nahar, K. ; Mubin, S. H., (2006). Slow arsenic poisoning of the contaminated groundwater users. Int. J. Environ. Sci. Tech., 3 (4) 447-453 (7 pages).

USEPA, (2006). Geologic controls on arsenic distribution and mobilization in pennsylvania groundwater. United State Environmental Protection Agency. EPA Grant Number: F5B20305.

Urik, M.; Littera, P.; Sevc, J.; KolencÃ-k, M.; CerÃansk Ã, S., (2009). Removal of arsenic (V) from aqueous solutions using chemically modified sawdust of spruce (Picea abies): Kinetics and isotherm studies. Int. J. Environ. Sci. Tech., 6 (3) 451-456 (6 pages).

Wegelin, M.; Gechter, D.; Hug, S.; Mahmud, A.; Motaleb, A., (2000). SORAS-a simple arsenic removal process.

WHO, (1993). Guidelines for drinking-water quality. World Health Organization, Geneva.

\section{AUTHOR (S) BIOSKETCHES}

Akter, A., Ph.D. scholar, Department of Civil and Offshore Engineering, School of Built Environment, Heriot-Watt University, Edinburgh, Scotland, EH144 AS, UK. and Assistant Professor, Department of Civil Engineering, Chittagong University of Engineering and Technology, Chittagong-4349, Bangladesh. E-mail: aysha_akter@yahoo.com

Ali, M. H., Ph.D., Professor, Department of Civil Engineering, Chittagong University of Engineering and Technology, Chittagong-4349, Bangladesh and Faculty of Civil Engineering, University Technology Malaysia, 81310 UTM Skudai, Johor Darul Ta'zim, Malaysia. E-mail: pdrmhali@yahoo.com

How to cite this article: (Harvard style)

Akter, A.; Ali, M. H., (2011). Arsenic contamination in groundwater and its proposed remedial measures. Int. J. Environ. Sci. Tech., 8 (2), 433-443. 